\title{
Status and Challenges of Equity Crowdfunding Development
}

\author{
Xiuping $\mathrm{Li}^{1}$ \\ ${ }^{1}$ School economics, Wuhan Donghu University, Wuhan 430072, China
}

Keywords:Equity crowdfunding, public offering, private

\begin{abstract}
As an organic part of the multi-level capital market, equity crowdfunding enriches the capital market level, provides possibility for multi-level financial services, promotes "public entrepreneurship and innovation”, and improves financial ecological of innovation and entrepreneurship. The rapid development of equity crowdfunding faces many constraints, such as the compliance problems of securities issue, regulatory problems of crowdfunding platform and investors' risk affordability problems. To address these challenges needs to establish the coexisting regulatory model of the license system of public equity crowdfunding platform and the filing system of private equity crowdfunding platform to establish the qualified investors standards of private equity and the investment limits of public equity crowdfunding in line with China's national conditions, to promote the combination of public equity chips and regional exchanges, and rationalize the convergence mechanisms of equity crowdfunding, listing and others.
\end{abstract}

\section{Equity crowdfunding concept}

According to the definition of China Financial and Economic Publishing book "Internet banking", crowdfunding refers to a financing way that the project initiators launch crowd strength, focus everyone's financial resources, capacity and channels to carry out an activity for SMEs, artists or individuals to start a business to provide the necessary financial assistance through the propagation characteristics of the Internet and SNS (Social Networking Services). According to the "Guiding Opinions on Promoting the healthy development of Internet banking” that People's Bank of China and other 10 ministries jointly issued, equity crowdfunding financing primarily refers to the public, small equity financing activities through the Internet form. Equity crowdfunding financing must be conducted through equity crowdfunding financing intermediary platform (Internet sites or other similar electronic media). According to the International Organization of Securities Commissions (IOSCO), the equity crowdfunding is financing activities that have access to financial resources from individual investors or institutional investors through Internet technology. Its main body includes three elements of financing side, crowdfunding platform and investors. Compared to traditional financing, equity crowdfunding is the essence of a small and a large, and financing threshold has decreased significantly with respect to private equity investment, which has opened up a new path for the new start-ups financing. Since then, the start-up financing channels for enterprises are no longer limited to banks, PE, VC and angel funds, while ordinary investors also have the opportunity to participate in some high-growth equity investments on companies return.

\section{Equity crowdfunding meaning and function}

In our financing system, the bank-based financing model has many drawbacks. On the one hand, the accumulated risks is easy to bring a systemic crisis in bank financing and financing system; on the other hand, banks snobs characteristics will lead to a large number of problems for SME financing 
which have become increasingly prominent. Furthermore, for the narrow investment channels, the multi-level investment needs of investors are not met. Therefore, deepening financial reform, improving the promotion of macroeconomic stability, supporting the development of a modern financial system and the real economy, and accelerating the development of multi-level capital market are not only objective need of corporate finance in the period of the rise of entrepreneurial boom, but also to adapt to different investment needs and risk appetite diverse needs, but also to prevent the economy of the overall level of leverage rapid rise in the need for the new normal. Develop multi-level capital market so that equity crowdfunding has become an important complement to traditional financial markets, which not only meets the financing needs of small and micro enterprises, but also help enrich the financial markets and the level of product, effectively play a role in boosting financial innovation on Technological Innovation.

\section{Equity crowdfunding status and trends}

In recent years, for the total amount of investment of private wealth and market HNWIs continue to maintain a rapid double-digit growth, equity crowdfunding provides an effective investment channels for high net worth crowd, breaking the investment path of traditional angel, PC, VE, which makes small, diversified and low-risk investment possible. Development of equity crowdfunding industry can be divided into two phases: the first phase is before 2015, the angels department, original department, everyone vote, the venture capital circles and other platforms can be considered a founding echelon of equity crowdfunding industry, and they lay the foundation for the development of the industry, and make a certain amount of elementary education for equity crowdfunding market. In 2015, Jingdong, Ali, Peace, north of Beijing crowdfunding, 36 krypton, and some other giants partnership circle and innovation platform continue to emerge in the first half of 2015, which has the industry background and strong financial strength to support, and these equity crowdfunding platforms can be regarded as equity crowdfunding industry force, so the development of the industry goes into the professional stage. Equity crowdfunding opened the era of low-threshold equity investments, but the quick access of professional bodies and industry giants has virtually raised the threshold for the industry.

Convergence of high-quality project resources, improved services after investment management, and investment projects led by institutional investors and well-known investors, the convenient launch of exchange equity share transfer and other advantages, are those that traditional equity crowdfunding organization cannot match in a short time. In the next years, there will be more money and incoming agency with strength entering equity crowdfunding market. In November 2014, Premier Li Keqiang proposed to carry out equity crowdfunding financing pilot to ease corporate financing difficulties in the State Council Executive Meeting at the first time. On July 18, 2015, the "Guiding Opinions on Promoting the Healthy Development of Internet banking” that People's Bank of China and other 10 ministries issued pointed that: Equity crowdfunding financing agency can make innovation and exploration to business model under the premise of compliance with laws and regulations, play a role in financing the equity crowdfunding as an integral part of multi-level capital market, and better service innovation start-ups. “Guidance” clear the significance of equity crowdfunding and business boundaries, which provides policy support and clear business direction for healthy development of equity crowdfunding next step.

\section{Equity crowdfunding form}

According to China's specific laws, regulations and policies, equity crowdfunding are transformed 
into three categories manifestations of angel type, membership type and certificated type.

(A) Angel type equity crowdfunding

Angel type equity crowdfunding is close to angel investors and VC mode. Investors look for start-up enterprises and projects through equity crowdfunding platform. Investor shares by venture angel investors are usually accompanied by a clear financial return requirements. Angel type equity crowdfunding platform is appropriate for the growth of outstanding high-tech corporate finance. Angel type equity crowdfunding modes are as follows: business projects are released on the platform, attract a sufficient number of small investors, full amount of financing, investors establish a limited partnership according to their investment proportion, then the limited partnership shares of corporate identity company is investment projects, hold Project Company to sell shares. If the project financing is successful through the platform, companies need financing to pay financing consulting fees for intermediate platform.

(B) Membership type equity crowdfunding

Membership type equity crowdfunding means that through the Internet social networking platform, investors generally use the same stock with the right way, the respective investors participate in the investment, and direct investment enterprises become shareholders. Based on the current prevailing cultural circles, combined with the unsatisfactory quality of service at present, many service establishments through crowdfunding way to attract investors that have resources and people can not only raise funds, but also lock a number of loyal customers. The most typical case in China of membership type equity crowdfunding is crowdfunding coffee. The main feature of crowdfunding coffee is that each participant needs to come up with a standard amount of public funds, and participants often participate in this crowdfunding with the attitude of holding circle and unrequited. Crowdfunding coffee is actually crowdfunding network circle. In reality, crowdfunding coffee faces the development of multiple bottlenecks, such as equal status of investors, and it is difficult to form a unified decision-making mechanism; single profit model and non-sustainable sources of funding; different crowdfunding contribution with unfair distribution of profits, etc..

(C) Certificated type equity crowdfunding

Certificated type crowdfunding refers to the funds raised through the sale of equity crowdfunding platform credentials and binding way, investors pay money to obtain the relevant documents, certificates or equity directly linked to corporate business projects, but investors do not become a shareholder of the company. The typical representative of certificated type equity crowdfunding is the make. V media and hocos, both of which are sold enterprises IPO to raise funds through the Taobao platform, by buying a membership card, the company's investors indirectly own stake in the enterprise. Compared with conventional financing, certificated type equity crowdfunding can effectively concentrate willingness to invest in the power of small folk, many of them can learn the bright spot: low threshold, fast financing, and risk diversification. In culture, media, creative services, products, and other fields, certificated type equity crowdfunding can play its own characteristics, develop funds required for financing in relatively smaller, more privacy circles set of enterprise. In accordance with the Securities Act, issuance of securities to non-specific accumulated more than 200 people, belong to public offering, and it needs to be approved by the securities regulatory authorities. In the development process of certificated type equity crowdfunding, once companies raise money on the line for the public, if the number of people exceeds a predetermined number, the commission will face penalties. Therefore, the current stage is stopped in this way, and with the clarity of equity crowdfunding policy and difficulty reduction of financing venture, certificated type equity crowdfunding will gradually become history. 


\section{Challenges faced by equity crowdfunding}

According to Article 10 of China's “Securities Act”, any behavior that provides non-specific public with offering securities is subject to the securities regulatory authority under the approval of State Council or the State Council authorized department before implementation. At general review of relevant existing laws and regulations, it can be found that the public offering requirement of securities is indeed very high, which need be approved by the competent authorities. Therefore, under the existing system environment, fundraisers who raise funds through equity, strictly speaking, is an act of unauthorized public offering of securities, which may not only suffer severe punishment of the administrative department, it is also likely to touch the red corporate bonds of Article 179 in "Criminal Law" without issuing shares, which will face jail. To avoid legal risks, China's current market equity crowdfunding sites have generally adopted a series of measures to avoid, but these measures reduce the equity crowdfunding financing efficiency to a considerable extent, and cannot completely get rid of the legal risk.

Although equity crowdfunding relates two parties, crowdfunding platform has played a vital role in the overall financing process. We can say that it is the appearance of raising public platform that explore and match their own funds for investment income and financing requirements between the two sides. To some extent, crowdfunding platform and securities companies are quite similar. However, compared to the harsh conditions and the strict regulation of establishment of securities companies, the crowdfunding platform in China is still in the natural growth stage. Operators design system entirely from the perspective of improving market attractiveness, although there are some good institutional innovation, they lack the necessary unified supervision. In addition, before the establishment of our more comprehensive enterprise credit system, if crowdfunding platform doesn't make a formal membership and improve the review mechanism for the qualification financier review, but blindly launches financing project for their own interests, it is likely to make the financing model of equity crowdfunding soon be filled with all kinds of junk stocks, and thus make the industry collapse rapidly due to loss of integrity.

Since equity crowdfunding income directly depends on the fundraisers' future business conditions, which has a strong uncertainty that will leads to high investment risk. In fact, for most of the companies that need to raise public equity financing, it is very difficult to raise funds from other traditional financing channels, and the business prospects and solvency of these enterprises is often difficult to guarantee. Faced with the investment way with high rate of return and risk, it is not suitable for ordinary investors to participate.

In addition, the project of equity investment is determined from the project selection of start-up to the development trend of the industry. From pricing project valuation to establishing a trust relationship between the investor and the platform as well as how to ensure the confidence of investors, while building liquidity and efficient investment channels, the development of equity crowdfunding faces numerous constraints.

\section{Countermeasures and suggestions}

Equity crowdfunding platform is mainly financing service platform for small and micro start-ups, and the too high set of equity crowdfunding platform threshold access does not make sense. For the public equity crowdfunding platform, taking into account the difficulty of technical and regulatory requirements, taking a relatively more stringent licensing system is more appropriate. For private equity crowdfunding platform, it is recommended that record-keeping system is appropriate. In setting the premise such as a registered capital of 5 million, the requirements of the executive team, 
platform information disclosure, financial supervision and other basic thresholds, to guide the compliance establishment and operation of equity crowdfunding platform can promote the healthy development of the industry.

"Private Equity Crowdfunding Supervision and Management Methods (Trial) Draft” makes "the minimum amount of a single investment project financing of not less than one million yuan of units or individuals" as a condition of sufficient qualified investors. According to the financing needs of small and micro enterprises and that Chinese investors have to raise public investment strength and ability to judge the actual situation, it should be more suitable for individual investors to adjust a single project to 100 thousand yuan. The public offering of equity crowdfunding should be set to an upper bound of single project financing and individual investment. The financing amount of individual project is considered from three million to five million yuan or even higher of 10 million yuan as the upper limit; but with respect to the investment upper bound for individual investor, taking into account the difficulties and operability to provide proof of income and assets, it is recommended to establish a double standard, that is, any investor can limit investment, not exceeding 10,000 yuan within 12 months. The investors that provide proof of their income or assets above a certain standard, can use a certain percentage of their annual income as a total investment crowdfunding limit.

Establish and promote the models of equity crowdfunding platform publishing and distributing financing projects, and transfer transactions through regional exchange or Internet financial assets trading center, and provide more legal and convenient path for the public to raise equity capital exit. Under certain conditions, such as requiring legal filing of crowdfunding platform, investment projects and investors registered in the case of compliance, the investors equity crowdfunding establish are allowed to be qualified investors of three new board.

\section{Acknowledgements}

Project Source: 2015 Youth Fund Project "Equity Crowdfunding Development under the Background of Public Venture and People Innovation" at Wuhan Donghu University

\section{References}

[1] Ahlers G K C, Cumming D, Günther C, et al. Signaling in equity crowdfunding. Entrepreneurship Theory and Practice, 2015, 39(4): 955-980.

[2] Liu C. Robust $\mathrm{H}_{\infty}$ Control for Satellite Attitude Control System with Uncertainties and Additive Perturbation. International Journal of Science, 2014, 1(2): 1-9.

[3] Agrawal A K, Catalini C, Goldfarb A. Some simple economics of crowdfunding. National Bureau of Economic Research, 2013.

[4] Valanciene L, Jegeleviciute S. Valuation of crowdfunding: benefits and drawbacks. Economics and Management, 2013, 18(1): 39-48.

[5] Thomas J. Making equity crowdfunding work for the unaccredited crowd. Harvard Business Law Review, 2014, 4: 62-75.

[6] O'Connor S M. Crowdfunding's Impact on Start-Up IP Strategy. Geo. Mason L. Rev., 2013, 21: 895. 